\title{
Investigation of Groundwater Potential Using Remote Sensing and Geographical Information System (GIS) Techniques in Fakai Local Government of Kebbi State, Nigeria
}

\author{
Mukhtar M. ${ }^{1}$, Umar A. B. ${ }^{2}$, Kaoje M. B. ${ }^{3}$ \\ ${ }^{1}$ Science Department, College of Agriculture Zuru, Kebbi State \\ ${ }^{2,3}$ Department of Physics, Kebbi State University of Science and Technology Aliero, Kebbi State, Nigeria
}

\begin{abstract}
Groundwater is one of the most precious natural resource which supports human health, economic development and ecological diversity. Remote sensing and Geographical Information System (GIS) Techniques have been effectively used for the investigation of the potentiality of groundwater resource in Fakai local government area. The dataset for this research work are Landsat 8 Operational land imager (OLI), ASTER DEM, Topographical map and Geological map from which the essential criteria were obtained. The study used Weighted Linear Combination approach which involves mathematical weighing and ranking of the criteria. Multi-criteria evaluation was carried out on all the criteria using the Weighted Linear Combination approach in ArcGIS 10.4. Spatial analysis was carried out on the derived result using the Suitability Index (SI) value created from pairwise comparison analysis. The suitability map for groundwater recharge in the study area was hence produced using the suitability index. The result shows four classes for the study area. The classes include highly suitable, moderately suitable, less suitable and least suitable. Thus, the area most suitable for groundwater are found most towards the northern part, around the center and some regions in the northern part of the study area this serves as an indicator that most of the study area has good potential for groundwater recharge.
\end{abstract}

\section{KEYWORDS: Groundwater, Remote Sensing, GIS, Satellite Image, Imaging}

\section{INTRODUCTION}

The investigation of groundwater potential using remote sensing and Geographical Information System is indeed a non-contact scientific means of obtaining information on the suitability nature of groundwater resources in a particular area. This idea invariably simplifies the application of other geophysical methods in groundwater exploration.

Groundwater is described as water found beneath the surface of the earth in underground streams and aquifers (Anomoharan, 2011). Groundwater is one of the most natural resource that supports human health and ecological diversity (Vidhya and Vinay, 2018). Laurence and Ojo (2012) noted that, groundwater is most generally free from odour, colour and has very low dissolved solid. It is also not usually affected by natural factors such as drought. Groundwater resources are dynamic in nature as they grow with the expansion of irrigation activities, industrialization, urbanization etc. (Das, 2008).

Remote sensing and GIS provide important data and tools for groundwater exploration (Jawad and Yahya, 2013). The application of these tools has opened new paths in water resources studies. Remote sensing provides multi-spectral, multi-temporal and multisensor data of the earth's surface (Choudhhury et al., 2003). One of the greatest advantages of using remote sensing and GIS for hydrological investigation and monitoring is its ability to generate information in spatial and temporal domain, which is very crucial for successful analysis, prediction and validation (Sarma and Saraf, 2002). However, its ability for covering large and inaccessible areas within short time becomes a very handy tool in accessing, monitoring and conserving groundwater resources.

Apart from the urban centers which has pipe borne water in Kebbi State, most rural communities depend on surface and groundwater. Even in the cities and urban centers, many communities depend on shallow hand dug wells which are mostly private owned. The prevailing drying up of boreholes, particularly during the dry season has become one of the major problems affecting the provision of water in Fakai local government area. This then compelled most communities to revert to old system of acquiring drinking from ponds, cut out streams and domestic wells which lead to re-occurrence of water borne diseases due to the contamination by wind, animals and other factors. However, the lack of availability of water source in the study area had made the modern irrigation farming extremely difficult. 


\section{International Journal of Current Science Research and Review}

ISSN: 2581-8341

Volume 04 Issue 05 May 2021

DOI: 10.47191/ijesrr/V4-i5-05, Impact Factor: 5.825

IJCSRR@ 2021

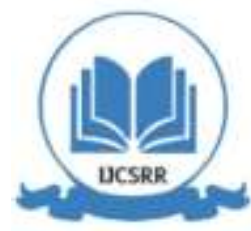

www.ijcsrr.org

Drilling of unproductive boreholes over the years has been a matter of concern to the inhabitants of most rural communities in Fakai local government area and most importantly to donor agencies and water managers in the country, thus, the need for the exploration and exploitation of the weathered and fractured aquifers in the study area is necessary to identify potential sources for groundwater and this could only be achieved by a combination of detailed geological, hydrological and integrated geophysical studies.

\section{STUDY AREA}

Fakai local government lies within longitude $5^{0} 7^{\prime} 0^{\prime \prime} \mathrm{E}$ and latitude $11^{0} 30^{\prime} 0^{\prime \prime} \mathrm{N}$ in southwestern part of Kebbi state, Nigeria. It covers an area of about 2247 square kilometers. It is bounded in the south by Marafa and Kamtu, in the north by Bula Maimi and Maidanga, in the west by Hawal and Rafin Gora and in the east by Mahuta and Garin Hausawa. The study area has a combination of high, low and undulating terrain. The elevation ranges from $178-482 \mathrm{~m}$ above sea level. The northeastern part of the area has a relatively high elevation which gradually reduces towards the southeastern part of the area. This terrain is mostly rocky. Hence, there is greater potential for groundwater recharge which is washed down from higher planes to lower areas.

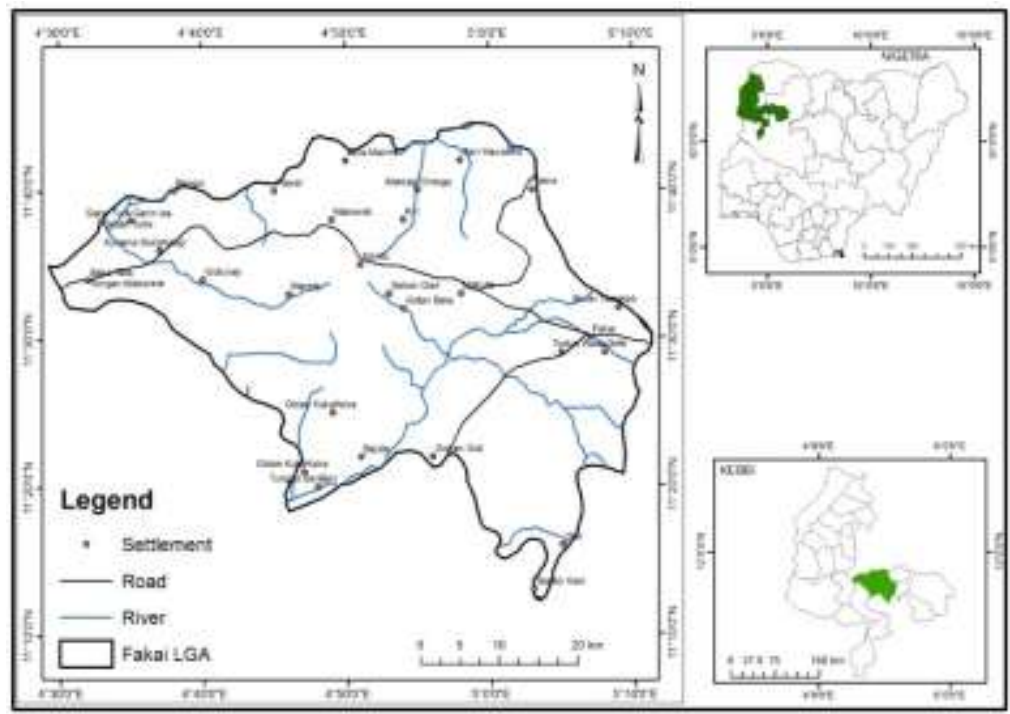

Figure I: Map of the Study Area

\section{MATERIALS AND METHODS}

This study was accomplished by the use of the followings: ENVI 5.3, ArcGIS 10.4, Microsoft Excel 2013, Microsoft Word 2013, Garmin handheld GPS receiver among others. The ENVI 5.3 and ArcGIS 10.4 were used for the image classification and GIS analysis. The Microsoft Excel was used to input the field data while Microsoft Word was used for the report writing. The Garmin handheld GPS receiver was used to collect coordinates on the field.

The method adopted for this work is basically in two phases in order to arrive at the suitability map. The factors influencing suitability were first determined and secondly, multi criteria evaluation (MCE) was carried out in a GIS environment. In the MCE, Weighted Linear Combination (WLC) approach which involves the ranking of each contributing factor was used. The datasets for this work are those whose spatial references can be determined. These datasets are: geology map, geomorphology map, topographic map, Landsat 8 OLI image, ASTER image and boundary of the study area.

Table I: Data and Data Sources

\begin{tabular}{|l|l|l|l|}
\hline S/N & DATA TYPE & SOURCES & RELEVANCE \\
\hline 1. & LandSat 8 OLI (30m resolution) & Global Land Cover Facility (GLCF) & $\begin{array}{l}\text { Land-use classification and lineament of the } \\
\text { study area }\end{array}$ \\
\hline 2 & ASTER DEM (30m Resolution) & Global Land Cover Facility (GLCF) & Geomorphology of the study area \\
\hline
\end{tabular}




\section{International Journal of Current Science Research and Review}

ISSN: 2581-8341

Volume 04 Issue 05 May 2021

DOI: 10.47191/ijesrr/V4-i5-05, Impact Factor: 5.825

IJCSRR@ 2021

Www.ijcsrr.org

\begin{tabular}{|l|l|l|l|}
\hline 3. & Topographical Map (1:50,000) & $\begin{array}{l}\text { Office of the Surveyor General of } \\
\text { the Federation (OSGOF) }\end{array}$ & $\begin{array}{l}\text { Drainage network and elevation of the study } \\
\text { area }\end{array}$ \\
\hline 4. & Geological Map (1:250,000) & $\begin{array}{l}\text { Nigerian Geological Survey } \\
\text { Agency }\end{array}$ & $\begin{array}{l}\text { Identifying existing geology in the study } \\
\text { area }\end{array}$ \\
\hline
\end{tabular}

\section{DATA PROCESSING}

\section{Image Processing}

The satellite images acquired for this work are Landsat 8 OLI scenes covering the study areas. Remotely-sensed spectral information was obtained from LandSat8 OLI image, the area of study was subset with the boundary of the study area from a full scene covering part of the Northwest Nigeria. The images were geometrically corrected in ENVI 5.3 environment to conform to the WGS 1984 UTM Zone 31 for spatial referencing compatibility with other data sets that will be used within a GIS environment. Radiometric correction was also performed on the images to enhance visualization of features. A false colour composite (543) was produced using bands which corresponds to the near infrared, red and green bands of the Landsat 8 OLI. Supervised classification using the maximum likelihood algorithms was performed by creating a training sample of land use features such as water body, settlement, cultivation, bare surface, rock outcrop and shrub land. The land use land cover map of the study was produced from the supervised classification.

\section{Lineament Extraction}

The original false colour composite of Landsat 8 OLI subset image was corrected for atmospheric influence on the image. The atmospheric correction was carried out on the image using the FLASH operation in ENVI 5.3 which converts the raw radiance and DN data from imaging spectrometer and rescaled it to reflectance data. Therefore, all spectra are shifted to nearly the same albedo. The resultant spectra can be compared with the reflectance spectra of the laboratory or filed spectra, directly. The panchromatic and cirrus cloud (band 9) bands have not been used in this study. Image enhancement was performed to extract lineaments that would not have been apparent from the images. Digital spatial operations were carried out on LandSat8 OLI image covering the area, contrast, edge enhancement filters were applied to the image to enhance the visual quality. The image was subsequently exported to ArcGIS 10.4, the lineaments seen on the image were digitized to produce a lineament map. Lineament density map was produced from digitized lineaments using the line density operation in spatial analyst tool.

\section{ASTER DEM Processing}

The ASTER satellite scenes covering the study areas were acquired for this study. The area of study was subset with the boundary of the study area from the mosaic scenes covering the study area. The images were geometrically corrected in ENVI 5.3 environment to conform to the WGS 1984 UTM Zone 31 for spatial referencing compatibility with other data sets that will be used within a GIS environment. Radiometric correction was also performed on the images to enhance visualization of features. The subset image was then exported to ArcGIS environment and the TIN generated with the spatial analyst tool in ArcGIS to produce the geomorphology of the study area.

\section{Processing of Analogue Datasets}

The topographic and geology maps were scanned using $\mathrm{A}_{0}$ Scanner and georeferenced to WGS 1984 UTM Zone 31 for spatial referencing compatibility with other data sets that will be used within a GIS environment. The maps were subset using the boundary of the study area. A geodatabase was created for all maps and on-screen digitizing was carried out on all the maps to extract the geology types, contours and drainage layer of the study area. The drainage layer was captured with their specific stream order. Drainage density map was produced from digitized drainage using the line density operation in spatial analyst tool. The contour lines were interpolated to create Digital Elevation Model while the layers of digitized geology types were converted to raster. The slope was created from the DEM of the study area.

\section{Data Analysis}

The study used Weighted Linear Combination approach which involves mathematical weighing and ranking of the criteria. First, the raster layer for Digital Elevation Model (DEM) was reclassified. Slope and Geomorphology were reclassified into five classes. The same process was applied on the geology and land use raster layer. Drainage and lineament density maps were also reclassified 


\section{International Journal of Current Science Research and Review}

ISSN: 2581-8341

Volume 04 Issue 05 May 2021

DOI: 10.47191/ijcsrr/V4-i5-05, Impact Factor: 5.825

IJCSRR@ 2021

www.ijcsrr.org

and ranked accordingly. Multi-criteria evaluation was carried out on all the criteria using the Weighted Linear Combination approach in ArcGIS 10.4. Spatial analysis was carried out on the derived result using the Suitability Index (SI) value created from pairwise comparison analysis. The suitability map for groundwater recharge in the study area was produced using the suitability index.

\section{RESULT AND DISCUSSION}

The results of the analysis performed on the different datasets discussed in methodology are presented below. Each dataset result, its implications and suitability for groundwater recharge in the study area is critically analyzed and discussed extensively.

\section{Drainage of the Study Area}

Drainage pattern is one of the most important indicators of hydrogeological features, because drainage pattern, texture and density are controlled in a fundamental way by the underlying lithology (Erhan et al., 2005). As drainage is an important physical factor that greatly contributes to the groundwater recharge, the drainage density was used to evaluate the groundwater recharge availability in the study area. Drainage of the study area is observed to be clustered and scattered across the study area. The drainage ranged from 33.17 to 396.69 (figure 4). The areas with high drainage density have a greater potential for groundwater recharge occurrence while areas with low drainage density have less potential for groundwater recharge.

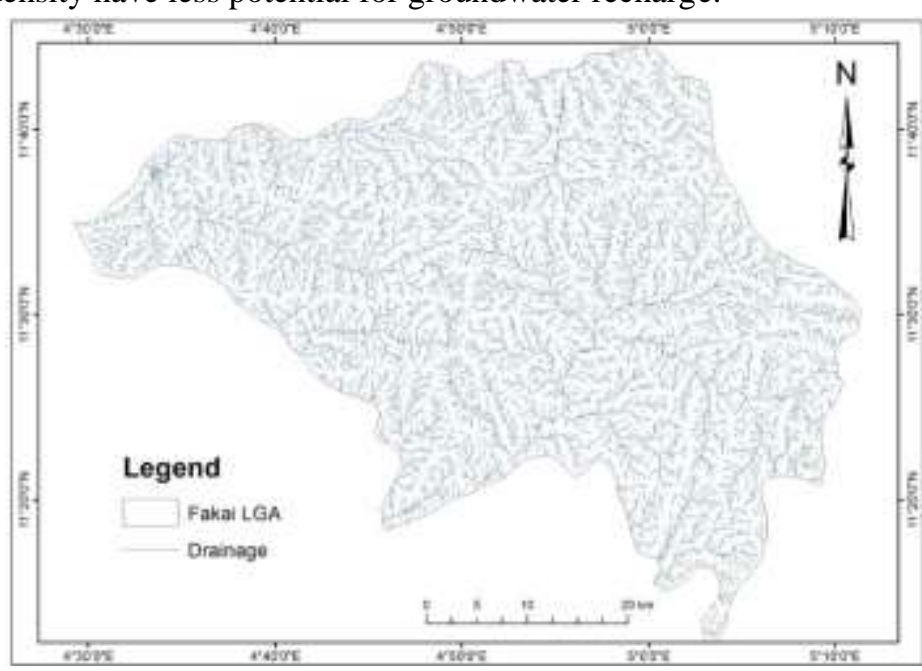

Figure II: Drainage map of the Study Area

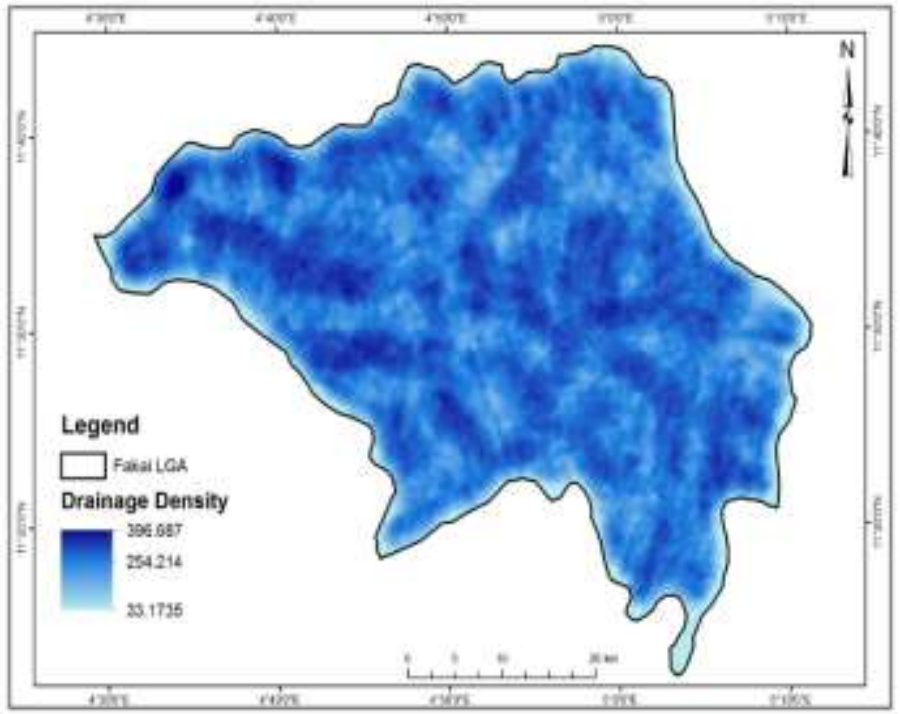

Figure III: Drainage Density of the Study Area 


\section{International Journal of Current Science Research and Review}

ISSN: 2581-8341

Volume 04 Issue 05 May 2021

DOI: 10.47191/ijcsrr/V4-i5-05, Impact Factor: 5.825

IJCSRR@ 2021

www.ijcsrr.org

\section{Lineament of the Study Area}

Lineaments give a clue to movement and storage of groundwater and therefore are important guides for groundwater exploration (Erhan et al., 2005). Lineament is one of the important physical parameters used in groundwater recharge; they act as accommodation zones for water supply. Hence, the lineament density was used to evaluate suitable areas for the occurrence of groundwater in the study area. Most of the lineaments are observed more clustered in the northern part while a few clustering observed at southern part of the study area (figure IV). The lineament density ranged from 0 to 212 with most of the study area having high density while very high density was observed towards the northern part (figure V). The areas having high lineament density have greater potential for groundwater recharge occurrence while those having low lineament density have lesser potential for groundwater recharge occurrence.

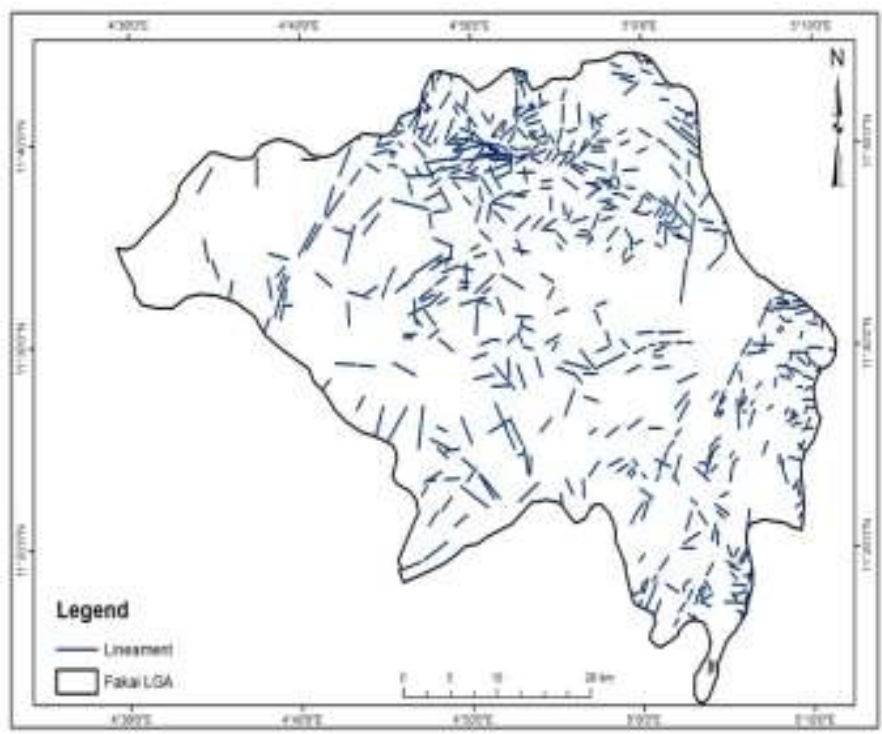

Figure IV: Lineament of the Study Area

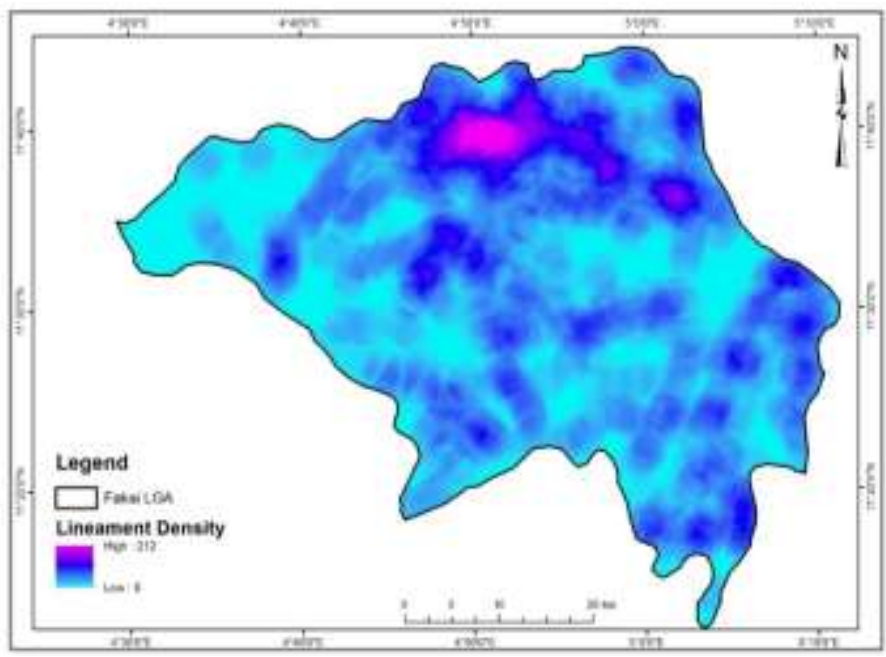

Figure V: Lineament density of the Study Area

\section{Topography of the Study Area}

Topographic data is a vital element in determining the water table elevations (Erhan et al., 2005). The topography of an area plays a very significant role in the groundwater recharge in a particular area. Since water responds to slope, a hilly area will discharge its water and sediments to lower elevation areas. The study area has a combination of high, low and undulating terrain. The elevation 


\section{International Journal of Current Science Research and Review}

ISSN: 2581-8341

Volume 04 Issue 05 May 2021

DOI: 10.47191/ijcsrr/V4-i5-05, Impact Factor: 5.825

IJCSRR@ 2021

www.ijcsrr.org

ranges from $178-482 \mathrm{~m}$ above sea level. The northwestern part of the area has a relatively high elevation which gradually reduces towards the southeastern part of the area (figure 6). This terrain is mostly rocky. Hence, there is greater potential for groundwater recharge which is washed down from higher planes to lower areas.

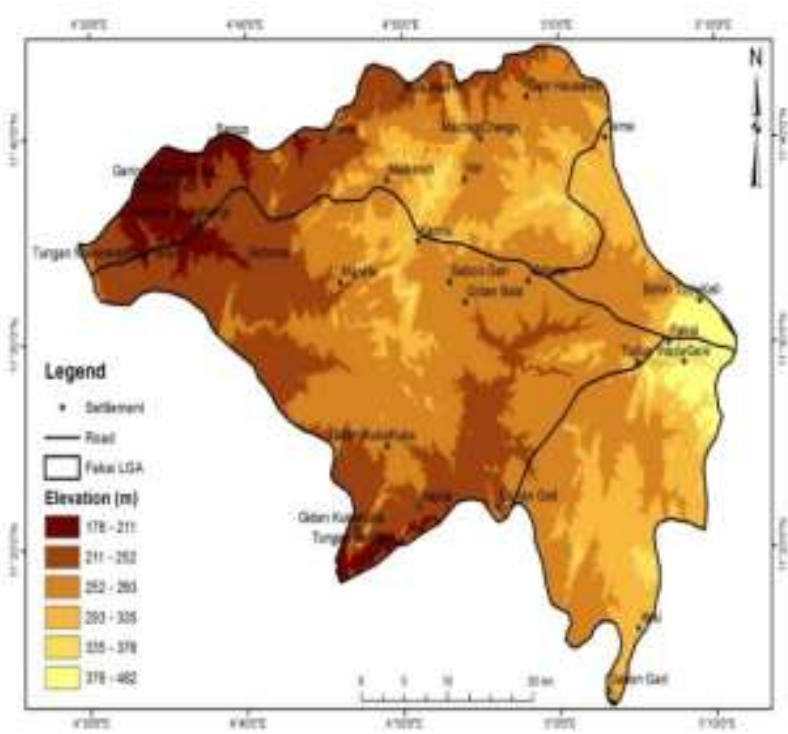

Figure VI: Topography of the Study Area

\section{Geology of the Study Area}

The geology is the most important factor in determining the occurrence of groundwater recharge because of the association to particular rock type or group of rocks. Groundwater recharge is primary associated with quartz mica schist and sandstones siltstones. The analysis shows that there are nine types of geology namely coarse pophyritic granite, granite gneiss, hornblende granite, metaconglumerate, migmatite, quartz mica schist, sandstone, siltstone, silicified sheared rocks and quartz veins and biotite and biotite hornblende granite, in the study area (figure VII). The migmatite is most dominant geology while sandstone and siltstone is the least dominant in the study area. The migmatite/granite gneiss has least potential for groundwater recharge occurrence while because of its hard resistant physical characteristics to weathering while the quartz micas schist/sandstone, siltstone have greater potential for groundwater recharge because they are more likely to be weathered and fractured creating accommodation zones for ground water accumulation.

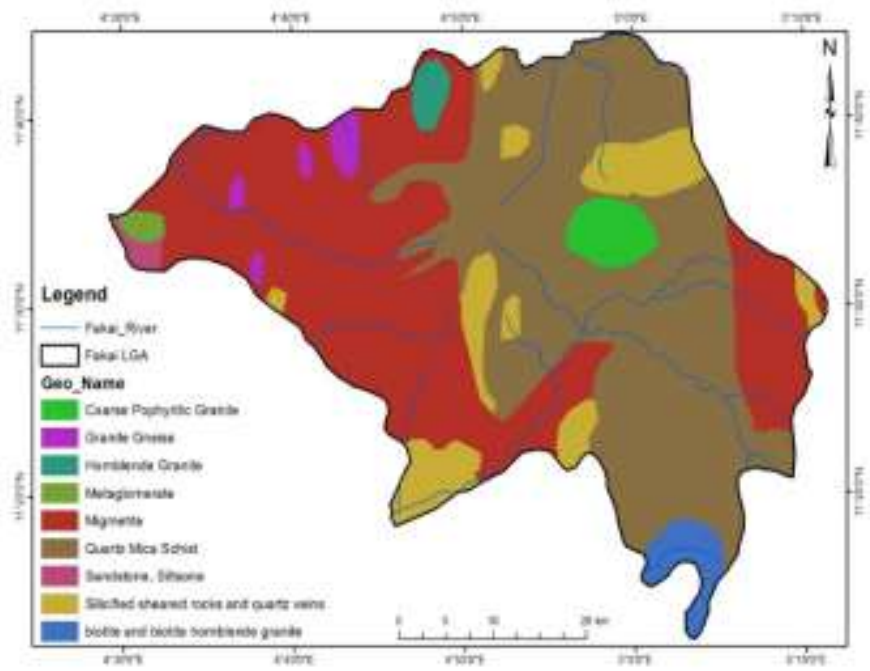

Figure VII: Geology of the Study Area 


\section{International Journal of Current Science Research and Review}

ISSN: 2581-8341

Volume 04 Issue 05 May 2021

DOI: 10.47191/ijcsrr/V4-i5-05, Impact Factor: 5.825

IJCSRR@ 2021

www.ijcsrr.org

\section{Geomorphology of the Study Area}

The geomorphology provides information on the terrain existing in the area which is also an important factor in determining groundwater recharge occurrence in the study area. The TIN created was used to evaluate the geomorphology of the study area. The result of the analysis indicates that the geomorphology ranged from 176 to $482 \mathrm{~m}$ in the study area (figure VIII). The lower geomorphology was most dominant in the study area while high geomorphology was sparsely scattered in the study. The areas with high geomorphology have higher potential for groundwater recharge occurrence while those with low geomorphology range have less potential for groundwater recharge occurrence.

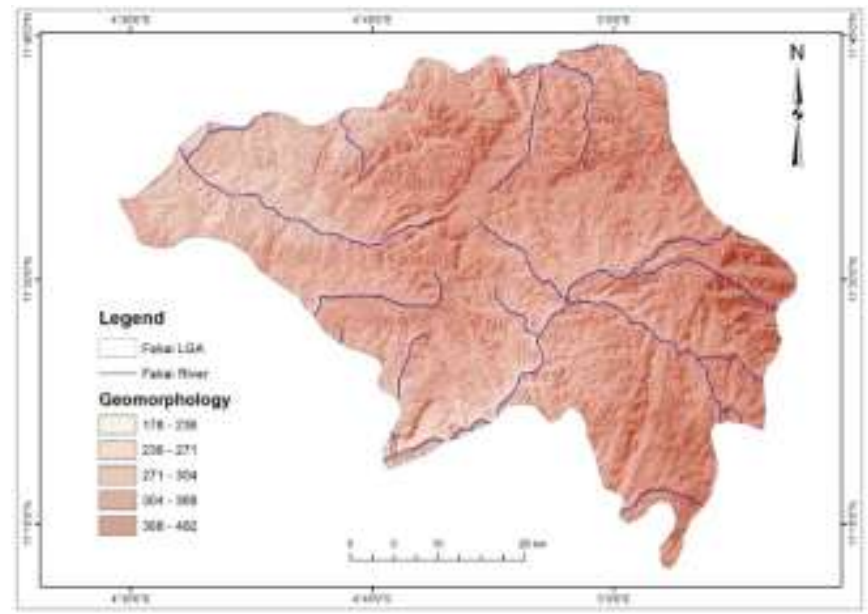

Figure VIII: Geomorphology of the Study Area

\section{Land Use and Land Cover of the Study Area}

Landuse and landcover are terrain characteristics that have significant impact on the spatial distribution of groundwater recharge. Therefore, landuse and landcover classification was carried out to ascertain the natural terrain characteristics of the study area and its contribution to groundwater recharge occurrence. The land use land cover identified five features namely waterbody, scrub land, cultivation, bare surface, settlement and rock outcrop (figure IX). The rock outcrop was the dominant land use class covering a significant area of the study area. The cultivation was next prominent land use class spatially distributed around the study area. The least dominant feature in the study area was the bare surface occupying a very small area followed by the settlement. In determining the site suitability occurrence, waterbody was rated most suitable for groundwater recharge.

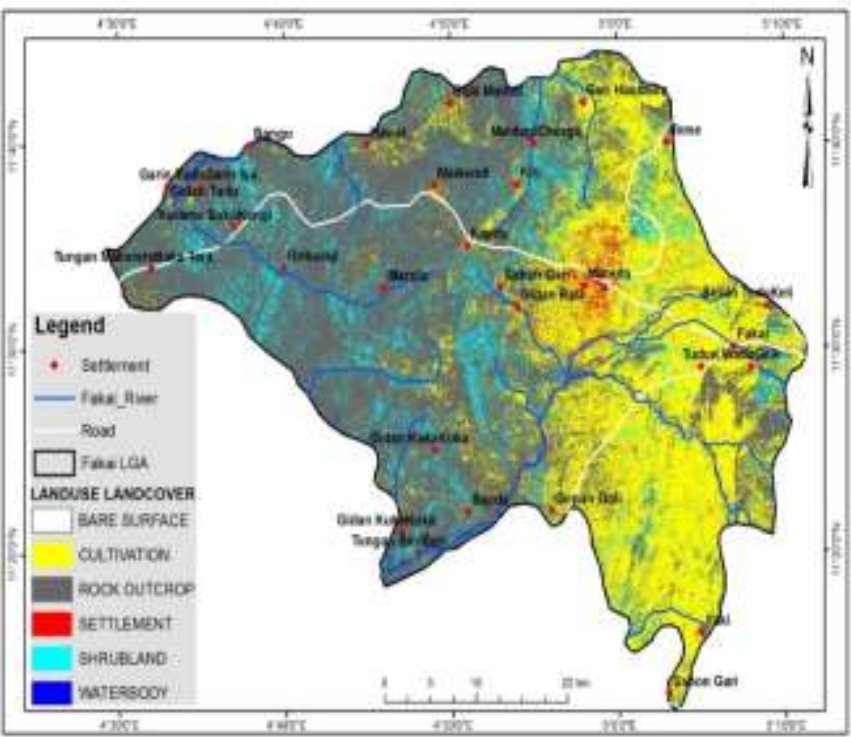

Figure IX: Land Use Land Cover of the Study Area 


\section{International Journal of Current Science Research and Review}

ISSN: 2581-8341

Volume 04 Issue 05 May 2021

DOI: 10.47191/ijesrr/V4-i5-05, Impact Factor: 5.825

IJCSRR@ 2021

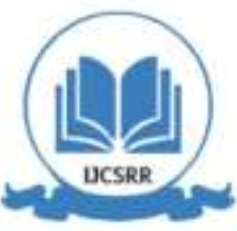

www.ijcsrr.org

\section{Suitability Areas of Groundwater Recharge in the Study Area}

In the groundwater recharge suitability map, the result shows four classes for the study area. These classes include highly suitable, moderately suitable, less suitable and least suitable (figure X). The highly moderately suitable areas are those areas with the highest potential for groundwater recharge occurrence and these represent $14 \%$. The area termed as moderately suitable are areas with potential occurrence of groundwater recharge but its suitability is limited because of one or more criteria. These areas occupy most of the study area representing $56.3 \%$. The areas termed as less suitable for groundwater recharge occurrence but its accessibility and quantity is severely limited by 2 or more criteria. These areas occupy $27.5 \%$ of the study area and the least suitable area occupy about $2 \%$. Thus, the area most suitable for groundwater recharge are found most towards the northern part, around the center and some regions in the northern part of the study. This indicates that the study area has some good potential for groundwater recharge.

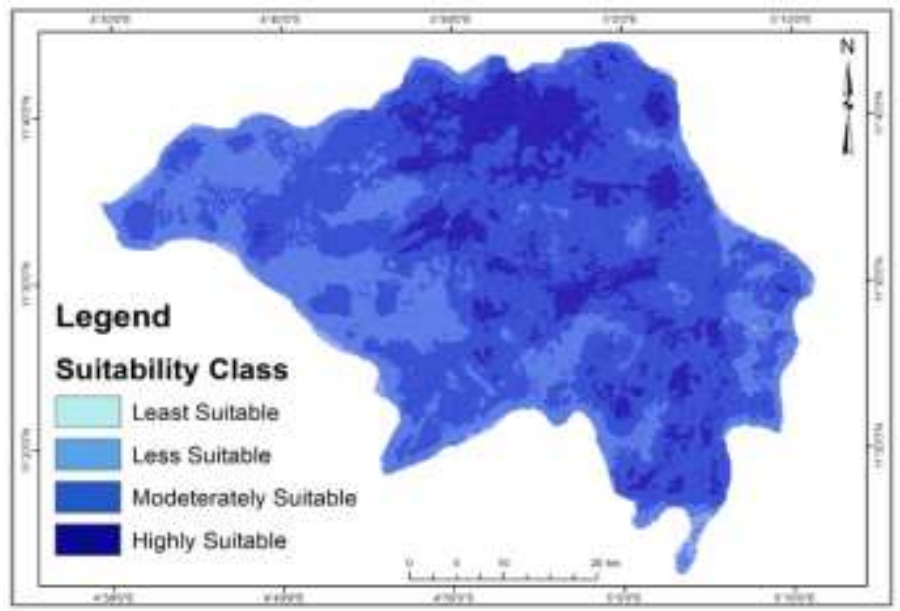

Figure X: Groundwater Recharge Suitability of the Study Area

\section{CONCLUSION}

The research focused on the potentially and usefulness of remote and geographic information system in groundwater recharge around Fakai local government area of Kebbi State. Analysis of several layers of data characterized by different geologic and geodynamic settings allowed a shortlisting of a series of criterions useful to recognize the areas suitable for groundwater recharge occurrence.

Groundwater recharge is an important process for sustainable management for both domestic consumption and industrial use. Hence, this study aims at providing information on groundwater recharge site sustainability in Fakai local government area (LGA) of Kebbi State. Spatial data such as geology, geomorphology, topography, Landsat 8 Operational Land Imager (OLI) and ASTER DEM were analyzed and information generated from the image was integrated into GIS geodatabase. The spatial data were reclassified base on their suitability for groundwater recharge, a suitability index was generated and suitability map produced. The result shows that about $14 \%$ of the study area is highly suitable, $56.3 \%$ moderately suitable, $27.5 \%$ is less suitable while only $2 \%$ is least suitable for groundwater recharge. Settlements including Maidagi, Chesgu and Kiri can be found within the highly suitable, Goburaji and Gidan Bala within the moderately suitable, Gonan and Goli within the less suitable and Ifaki in the least suitable area.

Finally, the integration of integration of results from remote sensing techniques with field, geological and other ancillary confirmed the value brought by the remote sensing application of groundwater recharge.

\section{RECOMMENDATIONS}

The study recommends that geophysical survey should be further carried in places of moderate to high potential regions to examine the quantity of water.

\section{REFERENCES}

1. Anomoharan, O. (2011), Determination of groundwater potential in Asaba, Nigeria Using Surface Geoelectric Sounding. International Journal of Physical Sciences, 6(33), 7651-7658. 


\section{International Journal of Current Science Research and Review}

ISSN: 2581-8341

Volume 04 Issue 05 May 2021

DOI: 10.47191/ijesrr/V4-i5-05, Impact Factor: 5.825

IJCSRR@ 2021

www.ijcsrr.org

2. ArcGIS, (2006), GIS Software, Version 9.2, Environmental System Research Institte (ESRI), New York.

3. Chowdhary, V.M., Rao, N. H. \& Sarma, P. B. (2003), GIS based decision support system for groundwater assasment in irrigation project area. Agricultral water Management

4. Das, D. 2008), GIS Application in hydrological Studies, Department of Environmental Science,University of Kalyani, India.

5. Erhan, S. · Aysen, D. \& - Mehmet, O. (2005), An Integration of GIS and Remote Sensing in Groundwater Investigations: A case study in Burdur, Turkey, Hydrogeology Journal, 13,826-834.

6. Jawad, T. A. \& Yahya, Y. A (2013), Application of GIS and Remote Sensing to Groundwater Exploration in Al-Wala Basin in Jordan. Journal of Water Resource and Protection, 5, 962-971.

7. Lawrence, A. O. \& Ojo, T. A. (2012), The use of Combine Geophysical Survey Method for Groundwater Prospecting in a Typical Basement Complex Terrain: Case Study of Ado Ekiti, Southwest Nigeria. Research Journal in Engineering and Applied Sciences 1(16), 362-376.

8. Sarma, B. \& Saraf, A. K. (2002), Study of Land use Groundwater Relationship Using an Intergrated Remote Sensing Approach. International Journal of the Physical Sciences, 6 (33), 7651-7656.

9. Vidhya, S. \& Vinay, Y. K. (2018) Identification of Groundwater Potential Zones using GIS and Remote Sensing, International Journal of Pure and Applied Mathematics,119,(17), 3195-3210.

Cite this Article: Mukhtar M., Umar A. B., Kaoje M. B. (2021). Investigation of Groundwater Potential Using Remote Sensing and Geographical Information System (GIS) Techniques in Fakai Local Government of Kebbi State, Nigeria. International Journal of Current Science Research and Review, 4(5), 358-366 